\title{
SEISMICITY OF THE TETON AND SOUTHERN YELLOWSTONE FAULT SYSTEMS
}

\author{
D. 1. Doser \\ R. B. Smith \\ Department of Geology and Geophysics \\ University of Utah
}

\section{Objectives}

Two summer field seasons of microearthquake monitoring in the Teton and Southern Yellowstone regions have been carried out in an attempt to define the seismicity of the area. Prior to this survey, only limited monitoring of the northern Jackson Hole and Mt. Leidy Highlands areas (Smith, Pelton and Love, 1977; Smith and others, 1977) had been conducted.

The first summer of monitoring (August-September, 1980) focused on seismicity in the southern Yellowstone-northern Teton region to determine how active the northern segments of the Teton fault were and whether the seismic activity extended into Yellowstone along traces of the Teton fault that are buried beneath the Pitchstone Plateau lava flows.

The second period of monitoring (August-September, 1981) took place in the south and central zones of the Teton fault. The central zone of the fault has exhibited Holocene displacement and we wished to determine the level of seismicity along this segment. Earthquake studies in the Palisade, Idaho region to the south, show a northward trend of earthquakes towards the southern end of the Teton fault. The monitoring of the southern zone will help determine how far this trend continues into the Jackson Hole region.

Another area of interest in the second period of monitoring was the region just east of Jackson where a felt earthquake occurred as late as July, 1981. It was hoped that aftershocks of this event would still be occurring during our monitoring period.

\section{Methods}

Earthquakes occurring in the region were recorded with portable battery operated seismographs. The paper records were changed every other day. During the 1980 survey nine stations were operated for seven weeks. In 1981 eleven stations were operated for a six week period. Three of these eleven stations reoccupied sites used in 1980 to insure continuity between surveys. Seismograms were also obtained from three permanent 
stations operated by Ricks College in eastern Idaho, including a station on the west slope of the Tetons. In addition, $\mathrm{P}$ - and S-wave arrival times for several earthquakes occurring in 1980 in southern Yellowstone were obtained from the U.S. Geological Survey's permanent Yellowstone array. After carefully correlating earthquakes between stations and determining $\mathrm{P}$ - and $\mathrm{S}$-wave arrival times, the earthquakes were located using an iterative least-squares hypocenter location computer program. In areas where several earthquakes occurred within one to two $\mathrm{km}$ of each other, composite fault plane solutions were obtained in an effort to determine the stress orientations of the region.

\section{Results}

Because of the later field period for the 1981 servey (August 3 - September 13) the majority of the earthquakes recorded at this time have not been located. Figure 1 shows the locations of all earthquakes recorded in 1980 and 14 earthquakes just located from the 1981 period.

The majority of earthquakes recorded in the 1980 survey appears to extend under the Pitchstone $\mathrm{Plateau}$, although no active fault traces are exposed in this region. The majority of the other 1980 earthquakes were located in the Gros Ventre range and beneath the Teton range. Most of the earthquakes appeared to have no correlation with mapped traces of Cenozoic faults. This makes it difficult to determine which faults may have the potential for damaging earthquakes in the future.

Two composite fault plane solutions were determined from the 1980 earthquakes (Figure 2) for the Pitchstone Plateau (area A in Figure 1) and Flagg Ranch (area B in Figure 1) regions. The fault plane solution for the Pitchstone Plateau indicated extension along one of two possible fault planes as noted. Without additional geologic information, it is difficult to determine which of the nodal planes was the actual plane of movement. The strike of both nodal planes is consistent with the north-south trend of the Teton fault. The fact that extension is occurring in this region may suggest that the Teton fault extends northward beneath the Yellowstone Plateau. The geology of the Flagg Ranch regions shows a fairly complex history of faulting, indicating that stresses in the region are probably not purely extensional. This is reflected in the fault plane solution for the region which shows compression along a north-south trending fault.

Although only a few of the 1981 earthquakes have been located, the seismicity during 1981 appears to be greater than that in 1980 . The fourteen 1981 earthquakes shown occurred within the period of August 3 to August 4 (only 37 earthquakes were located from the entire 1980 survey). These earthquakes were located along the central segment of the Teton fault, almost directly on the fault. 


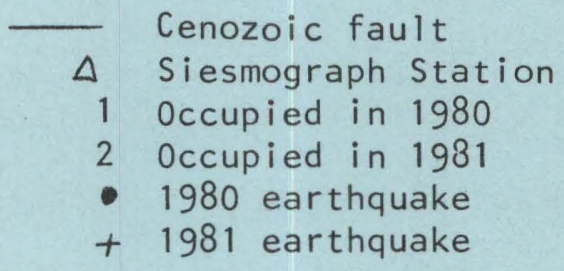

Figure 1. Teton microearthquake survey, 1980-81. 


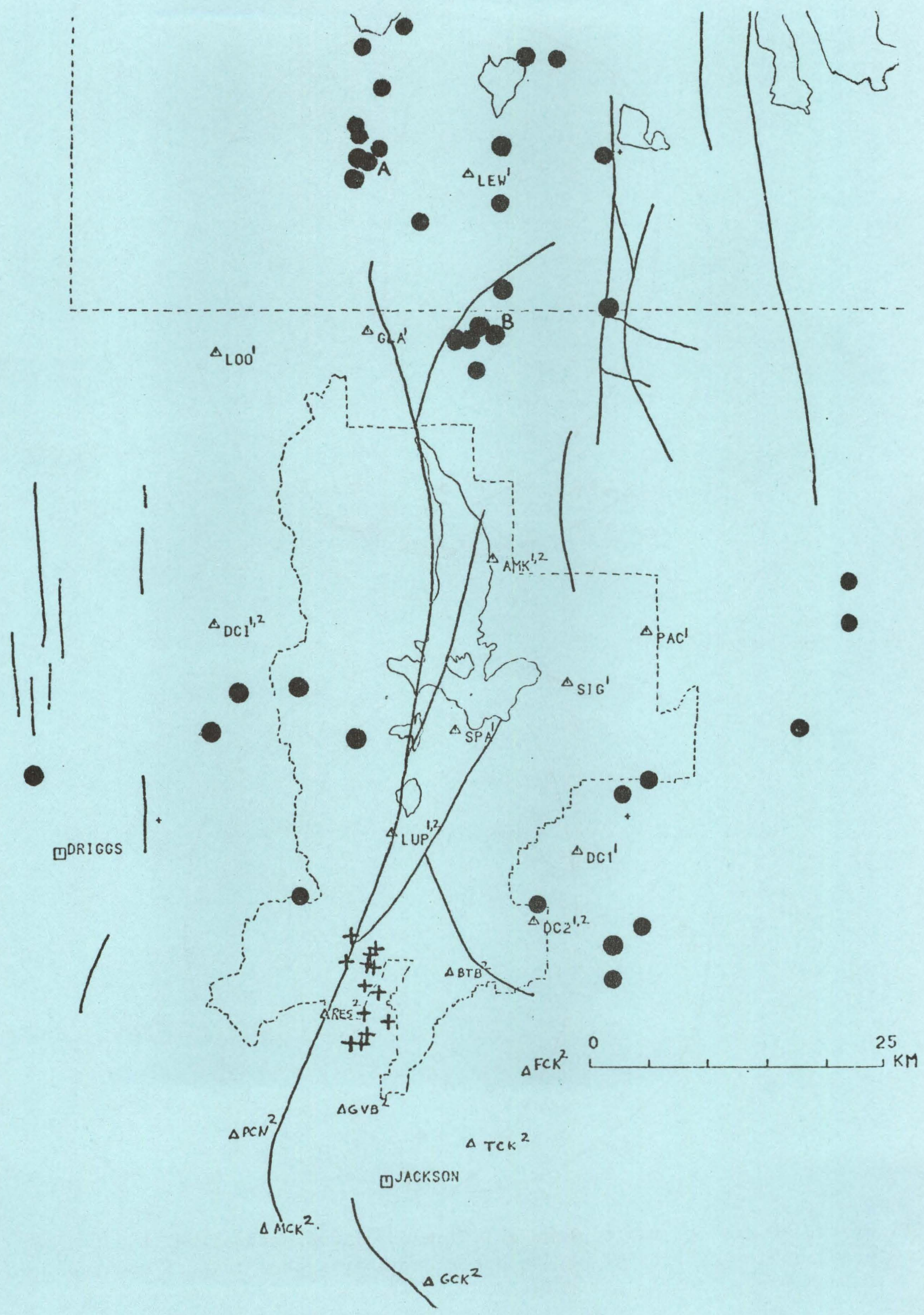



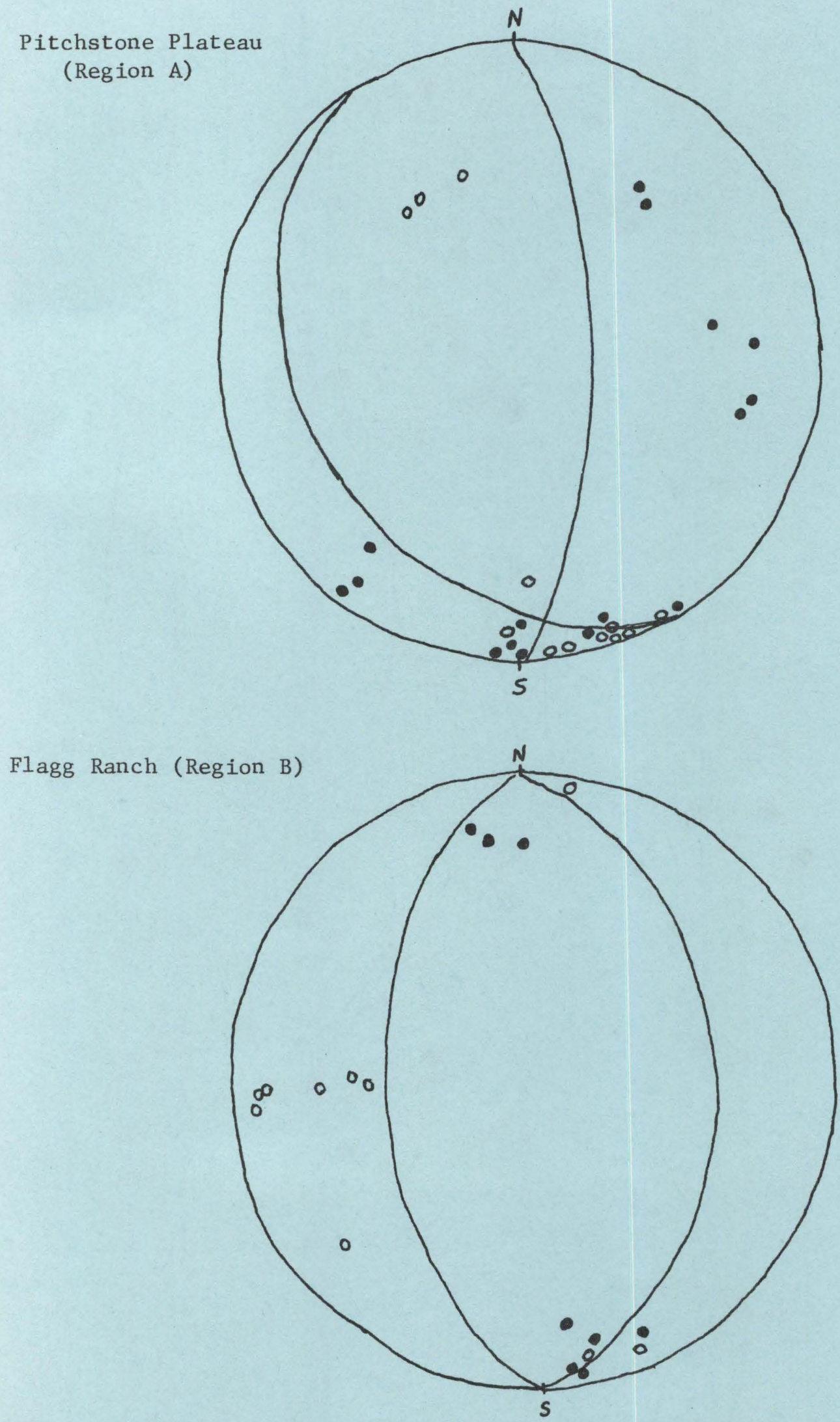

Figure 2. Composite fault plane solutions of microearthquakes. Equal area Stereographic projections of the upper hemisphere show initial compressions in black, initial extensions in white. 


\section{Conclusions}

Two periods of microearthquake monitoring $(1980,1981)$ in the Teton region have helped to define the overall seismicity of the region. More information will be forthcoming as work progresses on the location of the 1981 earthquakes.

\section{Literature Cited}

Smith, R. B., J.R. Pelton and J. D. Love. 1977. Seismicity and the possibility of earthquake related landslides in the Teton-Gros Ventre-Jackson Hole area, Wyoming, Contributions to Wyoming Geology, v. 14, p. $57-64$.

Smith, R. B., R. J. Shuey, J. R. Pelton and J. P. Bailey. 1977. Yellowstone hot spot, crustal properties from new earthquake and magnetic data, Jour. Geoph. Res., v. 82, p. 3665-3676.

\section{Acknowledgements}

We would like to thank the Grand Teton and Yellowstone National Park Service staffs and Dr. Ken Diem and his staff at the University of Wyoming-National Park Service Research Center for their help during our two summers of research in the Teton region. 